\title{
Seasonal balancing of revenue and demand in hotel industry: the case of Dubai City
}

\author{
Wasfi Alrawabdeh ${ }^{1}$
}

Received: 28 November 2020 / Accepted: 27 January 2021 / Published online: 27 February 2021

(c) The Author(s), under exclusive licence to Springer Nature Limited part of Springer Nature 2021

\begin{abstract}
For fact, a strong demand seasonality is observed in hotel industry, which needs early planning to prevent revenue declines. Cost cuts, although sometimes deemed tolerable, no longer help because expenditures have thresholds that hardly can be crossed. Increasing the revenue by raising rates, on the other side, adversely affects the level of demand. In low seasons, travelers are more sensitive to prices, and therefore, higher rates turn customers away to other rivals. To address the compromise between demand, supply, and prices, this work contributes to the existing literature by proposing a model that tests the balance of seasonal demands and prices to maximize hoteliers' profit. Specifically, we present an approach that finds the seasonal elasticity of demand at the optimum profit. The model is capable of assessing the balance of prices with the market demand, which helps in the assessment of hotels. To validate the model, data sets from Dubai international and domestic hotels were collected and used for benchmarking. It was found that international hotels confront higher seasonality as compared to local hotels. Only couple of hotels (Local and International) demonstrated successful efforts in seasonal balancing of prices with the demand. The demand was also found to be more elastic in the low seasons owing to high room offerings, while less elasticity is observed in the high seasons. The model acts as an effective tool for placing hotels on the board of price and demand, which assists the hoteliers to gain more insights toward benchmarking and evaluation.
\end{abstract}

Keywords Hotels $\cdot$ Hospitality $\cdot$ Seasonality $\cdot$ Price $\cdot$ Demand $\cdot$ Elasticity

\section{Introduction}

Most marketing managers in hotel industry expend a tremendous amount of time opening and closing channels of online travel agents while manipulating the rates to keep a good price-demand balance in the face of competitors. Some tend to use relatively sophisticated revenue software to address the issue of pricing. In hospitality pricing and sales control techniques, hoteliers should consider the elasticity of demand, which is a fundamental economic theory of pricing. The elasticity in hospitality business is defined by how the demand for hotel rooms differs in relation to prices. For instance, when a hotel increases its prices, a decrease in the demand is observed. As a result, this market is said to be elastic. Put differently, an elastic demand is a pattern that

Wasfi Alrawabdeh

rawabdeh@hu.edu.jo

1 Department of Management, Faculty of Economics and Administrative Sciences, The Hashemite University, Zarqa, Jordan can be noticed when prices affect the size of the demand in a specific market. Inelastic demand on the other hand, is observed when the prices have minimal effect on the size of demand. For instance, the change in oil prices may not significantly affect its demand.

Hotels in hospitality business encounter noticeable seasonality in the demand, which can be put into a range of high and low seasons. In the high seasons, hotel room prices seem not to be affected by the size of demand due to high occupancy rates. Therefore, the demand for rooms in the high seasons seems to be inelastic as compared to the low seasons. For this reason, the demand for rooms shows more responsiveness and elasticity to prices in low seasons, where hoteliers tend to work the prices and room availability/upgrades/upselling to overcome the drop in demand. Some factors that influence demand elasticity include the availability of rooms, the need, the purchaser's profits, the duration of stay, seasonality, "deal" pricing and demand/ value interpretation. Since this study regards Dubai city as a tourism model, Table 1 shows the occupancy rates for the years 2017 to 2020 . The seasonality pattern of the data can 
Table 1 Estimated occupancy of hotels in Dubai

\begin{tabular}{|c|c|c|c|c|}
\hline \multirow[t]{2}{*}{ Month } & \multicolumn{4}{|l|}{ Year } \\
\hline & 2017 & 2018 & 2019 & 2020 \\
\hline January & & 87 & 76 & 90 \\
\hline February & & 86 & 90 & 80 \\
\hline March & & 90 & 87 & 88 \\
\hline April & & 85 & 99 & 91 \\
\hline May & & 84 & 83 & 104 \\
\hline June & & 57 & 84 & 85 \\
\hline July & 61 & 67 & 61 & 88 \\
\hline August & 76 & 65 & 69 & \\
\hline September & 80 & 79 & 65 & \\
\hline October & 83 & 82 & 83 & \\
\hline November & 86 & 86 & 81 & \\
\hline December & 81 & 90 & 90 & \\
\hline
\end{tabular}

Data sources STR.com, Hotstat.com

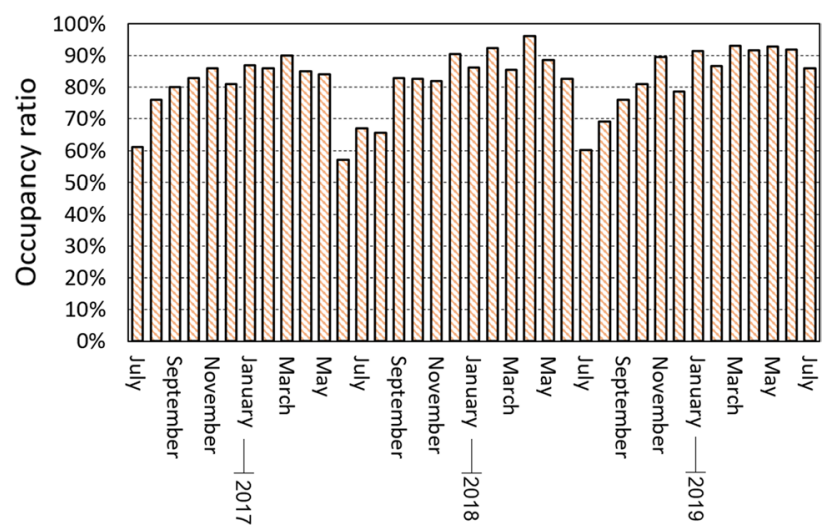

Fig. 1 Estimated occupancy of hotels in Dubai. Data sources STR. com, Hotstat.com

be observed in Fig. 1 where the low season can be noticed in the summer.

Contrary to realized demand in 2019-2020, almost all literature forecast studies of hotel industries predicted a significant increase in hotel reservations in Dubai owing to many new attractions among which the incredible wonder of Expo 2020. However, due to the pandemic of COVID-19 which appeared late in 2019, the entire hotel industry have encountered a landslide causing a huge drift in the numbers of tourists. Dubai, specifically has suffered a significant economic decline due to the pandemic and involuntary postponement of Expo 2020.

In the meantime, the investment in airports and hotels, as well as the diversification of the services sector are driving Dubai's development and appeal. The number and size of such attractions are projected to continue in increasing. Indeed, the rise in theme parks, cultural attractions, global village, Expo 2020 and affordable hotels have put Dubai's hospitality industry on track for continued growth past 2020. Significant tourism development such as IMG Worlds of Adventure, Dubai Parks and Resorts, cultural attractions like the Louvre in Abu Dhabi, city walks, La mer and JBR are expected to steadily attract leisure travelers for many years beyond 2020. Current tourism opportunities, modern destinations coupled with improvement of the existing venues, the introduction of new brands, and increased quality of living are projected to draw more visitors and raise the total duration of stay in Dubai.

Substantiated by a good deal of literature studies and business reports, seasonality is deemed evident in hotel industry. In United Arab Emirates (UAE), due to extreme summer temperatures, the low season is observed gradually end of June until September. Tourists prefer to visit Dubai in winter owed to moderate weather temperatures as compared to low ones in the north half of the globe. This seasonality affects the size of returns, which comes with more challenges to revenue managers who seek to increase profit. In low seasons, offers are excessively available which give the customers more room to bargain and seek better deals, resulting in higher elasticity in the demand. In contrast, high seasons demonstrate more strict prices with narrow margins for customers to impose their preferences. The alternating pattern in prices and offerings, upselling and upgrading requires better understanding of the price and demand relationships across the two seasons.

As such, this study extends the prior literature by demonstrating a profit maximizing model across the different seasons which helps hoteliers place their business on the performance map of other hotels. This paper contributes to the awareness of pricing practices of hotel industry in general and in Dubai in particular as one of the world business and tourism hubs. Here, a novel model that can be applied to hotel industry, for finding the right balance between prices, room offerings and upselling across different seasons is presented. The model finds the elasticities of different national and international hotels that should maximize the profit. Another major contribution to the field is the ability of the model to inform if a specific hotel conforms to profit maximization via the correct balance between prices and room offerings over different season.

\section{Demand and supply of Dubai's hotel industry}

Tourism, logistics, manufacturing and services sectors in Dubai provide growth opportunities beyond oil and gas, an industry on which many of the gulf region's economies in the Middle East rely on. The latest data from the STR hotel pipeline reveal that UAE has the highest number of new hotels and rooms under development in the Middle East and Africa area. 
Dubai now is well and truly known as a leading international destination for tourism. Over its comparatively short history, it has demonstrated significant achievements in tourism and was the fourth most visited destination according to the MasterCard's Global Cities Index in 2019, attracting 16.73 million visitors from over 233 countries around the world (Government of Dubai-Department of Tourism and Commerce Marketing, www.visitdubai.com/2019). Compared to 2018 , this represents a rise of $5.1 \%$, with doubledigit increase in arrivals from main source markets with an average of stay of 8 days per tourist and an average occupancy of $76 \%$ in 741 enlisted hotels. In 2019, guestroom inventory stood at 126,120-a 9\% YoY increase.

Another remarkable performance in 2019 was the guest accommodation market in Dubai, with the total number of occupied room nights exceeding 32 million for the first time, a $6.5 \%$ increase on the 3013 million occupied room nights

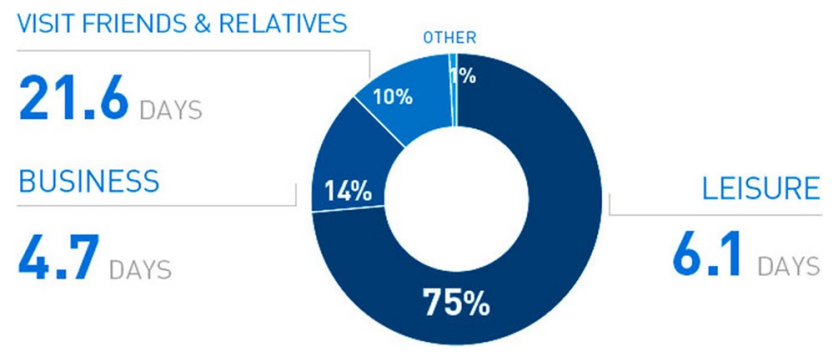

Fig. 2 Purpose of visit and length of stay in Dubai. Figure is reproduced from Annual visitor report 2019 by DTCM reported in 2018. Figure 2 shows the proportions of purpose of visits and the average length of stay.

In October 2019, the Average daily Rate (ADR) was 389.11 AED and the RevPAR was 266.57 AED. However, Dubai hotels experienced a significant decline due to COVID-19. Dubai's hotel industry reported its highest occupancy level since February-2019, according to preliminary data from STR in September 2020 with an increase in the occupancy rate to $45.4 \%$ and average daily rate of 284.15 AED and a RevPAR of $-50.6 \%$ to 129.03 AED.

The overall occupancy rate in 2019 was $76 \%$, which was a good and an important achievement considering the substantial rise in the supply of guestrooms. However, this indicates an effect on the overall average daily rate, which stood at AED 415 (-11\% YoY) and a (RevPAR), which totaled to AED 312 (-12\% YoY), showing low levels of customer affordability across source markets, but illustrating the sector's very strong global competitiveness.

Although Dubai's midscale and upper-midscale hotel offering continues to grow, its five-star guestroom inventory remains the dominant proportion of accommodation, accounting for $34 \%$ of the total availability. In December 2019, a total of 33,120 rooms were designated as four-star, accounting for $26 \%$ of the total availability of guestrooms. Figure 3 shows hotel inventory by category and performance in Dubai for the last 2 years (2018 and 2019).

According to DXB airport traffic, DXB airport in Dubai welcomed 86.4 million passengers in 2019, which gives an indication about the scale of tourism and hotel industry in the city (www.thenational.ae/2019; DTCM annual report). In the run-up to Expo 2020, this global trade fair is projected

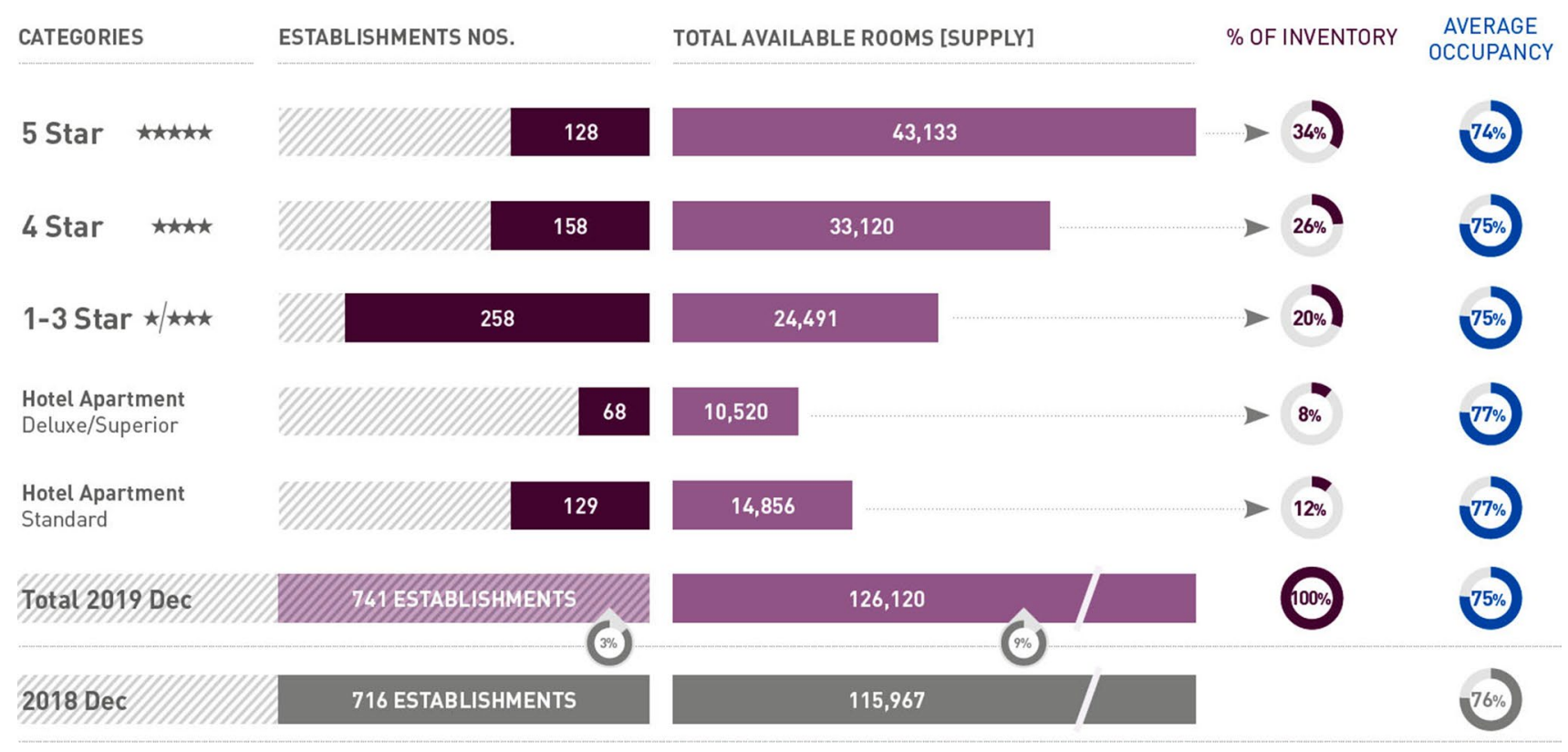

Fig. 3 Hotel inventory by category and performance for 2 years (2018-2019), reproduced from DTCM annual report 
to attract 25 million tourists to the city over a 6-month period, for this reason, the production of Dubai tourism has earned a further boost with a new supply of hotel rooms (www.visitdubai.com/2019).

As wealthy visitors come to stay in its fancy hotels or to buy some of its valuable waterfront properties, foreign money continued to pour into Dubai (Saed et al. 2020). Indeed, Dubai has been able to establish a leading role on the worldwide tourism map and become a destination for corporate travelers, tourists and shopping enthusiasts (www. dsc.gov.ae2019). It is projected by 2022 that the UAE hospitality industry is to hit $\$ 7.6$ billion, rising between 2017 and 2022 at a 5-year Compound Annual Growth Rate (CAGR) of $8.5 \%$, (khaleejtimes.com).

In total, the availability of hotel rooms in Dubai, the fourth most visited city in the world, is projected to exceed 150,000 , with the Emirate planning to complete 160,000 hotel rooms by the end of 2020 , the time to welcome 25 million tourists to Expo 2020, which was delayed until 2021 due to the pandemic of COVID-19. With 20 million annual visitors expected to visit Dubai in 2021, owed to the relief anticipated by providing COVID-19 vaccines allowing travelers to move freely around the world, such expectations likely to be valid in the year of 2022 due to FIFA world cup that is hosted in the neighboring country of Qatar.

Moreover, Dubai is known for its remarkable Meetings, Incentives, Conference/Conventions and Exhibitions/ Events (MICE) offerings. MICE have been reported to improve the demand for rooms and other associated bundles. In 2019, Dubai was designated as the world's leading MICE destination (hoteliesmiddleast.com). Nearly 400 global MICE and business activities were hosted by the Dubai World Trade Centre in the same year, attracting nearly 3.4 million delegates, a new landmark in its history.

\section{Literature review}

To maximize a firm's revenue over a short-term horizon in perishable services or products, revenue management has to be considered to contend with the costs and time constraint of the offered service or product. Such a category of problems can be found in airline ticketing, car rentals, hotel rooms and other types of perishable assets (Pimentel et al. 2019). Due to perishability nature of such assets, the maximization of its utilization can be addressed via explicit price modeling, or implicitly via manipulating the service packages (Chen et al. 2018).

More to the point, the matter of service bundling as a strategy for triage of customer segment according to their aversion to restrictions (minimum stay, flexible rate vs fixed rate, etc.), is an important issue, which is a critical element in hotels marketing and distribution strategy
(Beerli-Palacio et al. 2020). Travel bundles that offer additional amenities and passes to multiple attractions at a reduced rate are also attractive to a good deal of travelers. With Airbnb, for instance, travelers can enjoy additional services that may not exist in the same form once offered by OTA or direct reservation channels. However, some literature studies indicate that while hotel sales are adversely affected by both Airbnb and hotel supply, the extent of the effect of hotel supply on RevPAR is much greater than that of Airbnb (Dogru et al. 2020). The main concern in service bundles is that customers may not benefit from the additional services introduced to the bundles even they might pay less price for such additional services.

Implicit pricing in the hotel industry involves utilizing a variety of service packages. It results from dynamically making only certain service packages available for sale at a point in time-for example, upgrading hotel rooms at the same price, or making only the higher priced packages available for high seasons in which the price is indirectly manipulated. Discussions among hospitality and tourism society reveal that hotel room prices differ according to many attributes and characteristics such as the hotel site, size, class, age, quality, proximity to airports, transportation stations and tourist attractions (Latinopoulos 2018; Soler and Gemar 2018).

A little while ago, the Hedonic Pricing Models (HPMs) were used to identify the determinants of hotel room prices (Chen and Rothschild 2010; Schamel 2012; Ziqiong et al. 2011). In HPM, the prices are assumed to have linear relationship with features such as the site and situation factors (Zhang et al. 2011; Ziqiong et al. 2011). Other researchers as Israeli (2002) used brand and star ratings in a linear HPM to measure room prices. Under the hedonic price model, hotel rooms are considered as heterogeneous products whose prices are affected by a bundle of attributes and characteristics which extent beyond the hotel physical building to include other spatial features. Many studies that employ HPM highlight the factors of room prices such as star rating (Latinopoulos 2018), class (Ziqiong et al. 2011), service quality (Thrane 2007), age (Zhang et al. 2011), size (de la Peña et al. 2016; Soler and Gemar 2018), proximity to airports (Soler and Gemar 2018), tourist attractions (Santana-Jiménez et al. 2015), downtown (Lee and Jang 2012) and transportation stations (Zhang et al. 2011).

However, spatially referenced hotel attributes such as the location, the size, structure in the HPM come with few concerns that violate some basic assumptions, leading to biased parameter estimates and misleading significance tests (Kim et al. 2020a, b, c). Anyway, despite the importance of spatial attributes, the interest in HPM to model the prices is declining nowadays (Latinopoulos 2018; Soler and Gemar 2018; Zhang et al. 2011). 
Cleanliness, location size and class have been also heavily used to estimate prices (Ziqiong et al. 2011). Hotel amenities such as gift and food sales, local call service, complimentary breakfast, gym or AAA rate were addressed in many research articles (Nalley et al. 2019). Other forms of HPM include non-linear functions that have been also proposed in different studies that can be found in (Kim et al. 2020a, b, c). For instance, to estimate the quantitative influences of rural environment on lodging room prices, Santana-Jiménez et al. (2015) used a form of s-HPM for case studies from Spain and Taiwan. Other aspects such as sea view, location and service attributes have been addressed by Latinopoulos (2018) and Soler and Gemar (2018).

With the remarkable growth of online applications and internet coverage, online tourism is experiencing a very fast growth more than other channels. Prices are being transparent more than ever before with a good proportion of reservations made online (Stangl et al. 2016). As a consequence, a high dependence on electronic Word Of Mouth (eWOM) in hotel industry is being observed which results in a dramatic change of tourists behavior (Cantallops and Salvi 2014). Nowadays, eWOM impact is predominantly notable in the restaurants and hospitality industries (Pawlicz and Napierala 2017; Ye et al. 2011). This trust link between the service providers and the customers emerges from the mutual benefit of increasing the line of visibility in the services and prices. Sites such as Expedia, Trivago and Booking.com, allow the customers to search and compare the rates directly without the need for physical presence, which resulted in the advancement of online travel agencies (OTA). Online retailing in tourism has proven great efficiency, accessibility and less friction as compared to marketplaces that require physical presence. However, with prices being crystal transparent and generously accessible with less dispersion, additional challenges may be encountered by hoteliers due to the size of competition and services distribution channels (Hanna et al. 2019; Kim et al. 2020a, b, c; Nakamura et al. 2018; Sheremirov 2020).

In the past two decades, OTAs have expanded exponentially, driven not only by developments in e-commerce, but also by fortuitous business conditions. In 2017, OTAs had nearly $40 \%$ of the online travel sector in the United States (PhoCusWright 2018).

Owed to transparency and accessibility resulting from the recent boom in technology, pricing parity between booking channels has become more difficult, thereby changing the way consumers book hotel rooms. Rate parity is a strategy that refers to fixing the same rate for customers crosswise all distribution channels via arrangements between hotels and OTAs (Haynes and Egan, 2015; Kim et al. 2020a, b, c). Under such agreements, hotels cannot deliver lower room rates to their direct networks than what they offer to OTA mediators, which eliminate competition. Nevertheless, rate parity has been outlawed by some European countries such as Germany and France in 2015 (Nicolau and Sharma 2019). Recent environmental trends are moving away from rate parity to more transparent systems where hotels have greater autonomy over price setting than ever before by incorporating efficient management strategies of revenue (Sharma and Nicolau 2019). Such a transparency provided a new era for coopetition where hospitality service providers have to rethink on how to manage their revenues and stay in the market (Ivanov and Piddubna 2016).

Moreover, shifts in the global economy affect the hospitality industry due to external factors such as international instability, extremism, natural disasters, pandemics and economic uncertainty (Baud-Bovy 1982; Leong and Hui 2014). In such a volatility, hoteliers should closely track the numerous macro-economic factors impacting the industry before making critical strategic decisions. Indeed, the demand for hotel reservations is becoming more responsive to prices, which affects hotel sales and earnings (Arora and Mathur 2020).

Evaluating external variables that affect the productivity of hotel industry such as the regional economic factors is important to enhance standardized resort hospitality services (Yang and Cai 2016). Past studies have indicated a range of external influences on hotels performance such as connectivity, national economic climate, disaster events and market transparency (Assaf et al. 2015; Assaf \& Cvelbar, 2015). Hotel efficiencies have been analyzed in both parametric and non-parametric models. Data Envelopment Analysis (DEA) remains one of the most popular non-parametric approaches used to analyze efficiencies (Zhang et al. 2020). While many hotel chains in different countries rely on international tourism, some may not encounter the same demand as in China which ranks first in its domestic tourism according to (WTO 2018). However, recently, several provinces in China have promoted the development of high-end and luxury hotels, anticipating further venture to improve the tourism business and enable it gain higher revenues (Wu and Yang 2018).

Behavior-based price discrimination (BBPD) is usually analyzed in contexts that are featured by perfectly inelastic demand, depending on the customers' history of purchase and favorites; however, it was shown by Esteves and Reggiani (2014) that firms are worse off under BBPD, though; as demand elasticity increases the adverse effect of BBPD on profits gets smaller. While it might be difficult to identify previous customers and their purchase behavior and preferences in hotel industry, however, with hotel industry undergoing a major change in its customer interfaces, alliance with hotel different associates, hoteliers may be able to use the customers' historical information and their past preferences to offer different prices and/or service.

It was reported that as of 2012, two out of three travelers used online booking. It is now evident that online channels 
are the first choice for customers seeking hotels as compared to offline media like magazines or TV ads (Botts et al. 2012). Transparency nowadays is clear to the level where customers seamlessly can compare prices of the same hotel room offered by different OTAs. Such a transparency and shift to online distribution channels have contributed to greater price and demand elasticities and there is no sign of those trends braking down in the future.

Nevertheless, tourist attractions with a higher level of tourism sophistication have established business characteristics, like open market entry, diverse customer preferences and supportive policies that invite new customers and competitors (Zervas et al. 2015). In addition, hotel suppliers are grappling with rising demand and intense pressure from market consolidation (Chang et al. 2019).

In relation to the different aspects discussed above that shape the price and demand patterns, our goal in this work is to address the issue of balancing prices with the demand under seasonality conditions. We suggest a profit maximization model that finds the elasticities of the demand for a set of national and international hotels in fabulous city of Dubai. The model will place each hotel on the price-demand performance map by demonstrating new revenue-occupancy ratio relationships that best describe the right balance between prices and demands.

\section{Elasticities of demand}

The conventional price-demand curve is always downward sloping revealing the fact that higher prices result in less demand and vice versa. However, in goods/services that are characterized by exclusive existence and appeal as a status mark, a Veblen good is a one for which demand rises as the price increases. Nonetheless, evidences of rivalry effects on hotel prices indicate that room prices increase when rooms' availability among direct competitors decreases (Abrate and Viglia 2016). From the industrial organization viewpoint, a negative relationship is the most accepted notion between hotel prices and room offerings (Becerra et al. 2013).

When hotels concentration is high which leads to increased quantity, the prices will drop down. In contrast, scarcity leads to higher prices as a natural response. Figure 2 shows the trend between the offerings and prices where the revenue is the price times the quantity (Fig. 4).

The elasticity is a measure of responsiveness to changes in prices. It is simply the percent change in quantity divided by the percent change in the prices, which is mathematically expressed as:

$e=\frac{p}{q} \times \frac{\mathrm{d} q}{\mathrm{~d} p}$

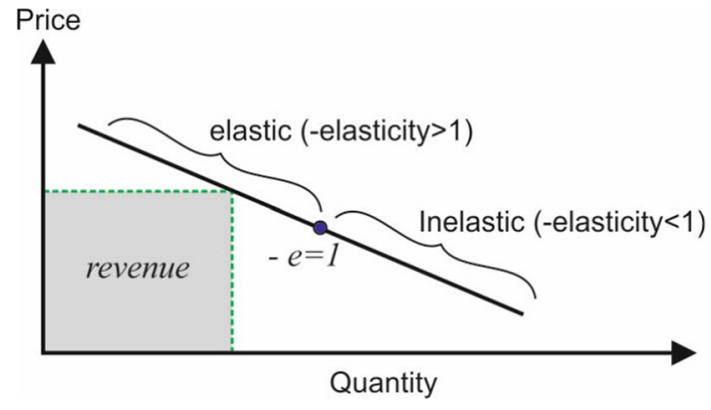

Fig. 4 Elastic and inelastic regions of the demand

where $p$ is the price and $q$ is the offered quantity. The above expression usually returns a negative number for inversely proportional demand pattern as a function of the price. Note that different revenues will result from different price settings at which different elasticities are found. This interpretation of demand responsiveness offers decisive insights into pricing policy formulation.

Demand and price elasticities are applicable in different business platforms. In hospitality business, hoteliers ought to take advantage of demand elasticity. It has been repeatedly reported that room prices affect travelers and tourists differently. Different price sensitivity for the business segment can be observed as compared to leisure. A business traveler has historically displayed a far lower degree of price volatility than a recreational consumer for equivalent room rate variations. Not only the type of customers, the seasonality also plays an important role in prices. The variation in reservation prices in the low seasons appeared to be higher than those in the high seasons, allowing for more elasticity in the low season owed to higher customer responsiveness to prices.

Moreover, the rates are also affected by the price tolerance provided to travel agents or other reservation channels. Hotel shoppers have different preferences when they seek hotel reservations, those include (1) pay whatever price is available, (2) pay what they think is a fair price, (3) pay negotiated rates and (4) try the least expensive price, all will affect the willingness to pay, thereby, increasing the elasticity.

Managing the demand and prices is also achievable via incorporating upselling and upgrading which contributes to limiting price cuts. It is more convenient to give special offers or upgrades to customers who already reached a buying decision rather than convincing a customer to take a more costly option. Online reservations has made a revolt on the way customers think and compare prices. According to some media sources surveys, 3 out of 4 probable travelers go to some sort of travel site before booking and 8 out of 10 use a search site. Online booking platforms offer no panic transactions and no front desk last second decisions. 
Accessibility, visibility and transparency have made the demand more elastic due to apparent responsiveness to prices. Ultimately, elasticity provides a feeling of how guests respond to competitive pricing and help build better insights to market.

Social networks also offer pricing choices for hoteliers. Since travelers tend to be suspicious of ads that focus too strongly on ratings, platforms such as Facebook, Instagram, TripAdvisor and Twitter now have a huge effect on travel decisions and consumer behavior. It is apparent now days that the elasticity is increasing due web/phone applications, online access, increasing line of visibility and transparency evidenced by higher customer responsiveness.

\section{Profit maximization elasticity model}

In hotel metrics, the Revenue Per Available Room (RevPAR) is a measure that accounts for the average daily rooms revenue generated per available room. Hotels can also derive their revenues from other sources such as management of the property, licensing of the brand, food and beverage sales and other amenities that may not be immediately associated with the room. However, RevPAR remains a key indicator for revenues in hotel industry.

RevPAR is simply measured by the ratio of Total Room Revenue to Total Rooms Available. Not to be confused with the available daily rate (ADR) which measures the average rental revenue earned for an occupied room per day. The occupancy rate $O$ on the other hand is a percentage of the available rooms used for a specific period. It can be calculated as the total paid (occupied) rooms divided by total available rooms. Occupancy also equals RevPAR/ADR. While the demand gradually moves between its highs and lows, averaging the demand over two seasons seems to be the most acceptable notion. Here, assuming that the demand for rooms exhibits a seasonal pattern of two high and low seasons ( $l$ and $h$ ), the number of utilized rooms will be $O \times n$ for an occupancy rate $O$ where $n$ is the number of rooms. Accordingly, RevPAR of the two seasons can be expressed as a function of the occupied rooms as follows:

$R_{\mathrm{PAR}}^{i}=f^{i}\left(O^{i} n\right), \quad \forall i=l, h$

where $R_{P A R}^{i}$ is RevPAR, the average revenue per available room that is collected in season $i$ and $f^{i}$ is a continuously differentiable revenue function. The number of available rooms $n$ is assumed to be the same in the two seasons, meaning that no expansion or drop in rooms is experienced between the two seasons. In this model, we assume two cost components for operating a single room, those are the fixed and variable costs. While the fixed cost $k$ may have insignificant variation across different seasons, the variable cost is affected by seasonality as it depends on the usage level. The cost of operating the occupied rooms of every season are therefore given by:

$C^{i}=k+c\left(O^{i} \times n\right), \quad \forall i=l, h$

where $c$ is the variable cost per room. From the findings in $(2,3)$, the profit function shall be the difference between the revenue and the costs, which is expressed as:

$p^{i}=\left(O^{i} n\right) f^{i}\left(O^{i} n\right)-\left(k+c\left(O^{i} \times n\right)\right), \quad \forall i=l, h$

With this profit expression, one can find the occupancy rate at which the profit is maximum. Of note, the profit in the high season is independent from that on the low season and vice versa, hence the first order conditions necessary for finding the maximum profit with respect to $O^{i}$ is found by:

$\frac{\mathrm{d} p^{i}}{\mathrm{~d} O^{i}}=f^{l}\left(O^{l} n\right)+\left(O^{l} n\right) \frac{\mathrm{d} f^{i}}{\mathrm{~d} O^{i}}-c, \quad \forall i=l, h$

Equating the above by zero for all seasons yields:

$c=R_{\mathrm{PAR}}^{i}+\left(O^{i} n\right) \frac{\mathrm{d} f^{i}}{\mathrm{~d} O^{i}}, \quad \forall i=l, h$

Since the fixed cost $k$ should be the same across the seasons, we get:

$R_{\mathrm{PAR}}^{h}+\left(O^{h} n\right) \frac{\mathrm{d} f^{h}}{\mathrm{~d} O^{h}}=R_{\mathrm{PAR}}^{l}+\left(O^{l} n\right) \frac{\mathrm{d} f^{l}}{\mathrm{~d} O^{l}}$,

Take $R_{P A R}^{i}$ as a common factor in both sides to get:

$R_{\mathrm{PAR}}^{h}\left(1+\frac{\left(O^{h} n\right)}{R_{\mathrm{PAR}}^{h}} \frac{\mathrm{d} f^{h}}{\mathrm{~d} O^{h}}\right)=R_{\mathrm{PAR}}^{l}\left(1+\frac{\left(O^{l} n\right)}{R_{\mathrm{PAR}}^{l}} \frac{\mathrm{d} f^{l}}{\mathrm{~d} O^{l}}\right)$,

To find the elasticity as a function of the quantity $O^{i} n$, let $q^{i}=O^{i} n$ and $y=R_{P A R}^{i}$, where $d q^{i}=n d O^{i}$ and $d y=d R_{P A R}^{i}=n d f$, hence using (1), the elasticity will be expressed as:

$e^{i}=\frac{\mathrm{d} f^{i}\left(O^{i} n\right)}{\mathrm{d} R_{\mathrm{PAR}}^{i}} \frac{R_{\mathrm{PAR}}^{i}}{O^{i} n}, \quad \forall i$

As a result, the above expression reduces to the following:

$R_{P A R}^{h}\left(1+\frac{1}{e^{h}}\right)=R_{P A R}^{l}\left(1+\frac{1}{e^{l}}\right)$,

Dividing by $R_{P A R}^{l}$ results in:

$\frac{R_{P A R}^{h}}{R_{P A R}^{l}}=\left(\frac{e^{h}}{e^{l}}\right)\left(\frac{1+e^{l}}{1+e^{h}}\right)$

where $e$ is the elasticity of the demand with respect to RevPAR. The expression in (11) is valid for the maximization 
of revenue, which shows that the revenue ratio between the two seasons depends on the elasticities of demand, mainly the fraction $\left(\frac{e^{h}}{e^{l}}\right)$ since the other fraction has higher tendency to be 1 for the same ratio. As a remark, to have $R_{P A R}^{h}>R_{P A R}^{l}$, the condition $e^{h}>e^{l}$ must hold, meaning that raising the prices in the low season could be beneficial to maintain optimality. This is the case when the elasticity at the high season is less than that at the low season as shown in Fig. 3. For instance, when the elasticity of the high season is -1.2 and that of the low season is -1.4 , the ratio will be 1.71 , where at this ratio, the high season revenue is $71 \%$ higher than that of the low season (Fig. 5).

The two conditions in (6) will result in the following ratio of the high to low occupancy rates:

$\frac{O^{h}}{O^{l}}=\left(\frac{1+e^{l}}{1+e^{h}}\right)$

Here, the room occupancy in the high season exceeds the occupancy in the low season only when the demand for rooms in low season is more elastic to the revenue per available room than the high season. This is an expected behavior since in the low season, customers have higher variety of available hotels and the demand is affected by the prices due to many hotel offerings. Using the ratio of (11) and (12), the new expression for the revenues ratio will look like the following:

$\frac{R_{P A R}^{h}}{R_{P A R}^{l}}=\frac{O^{h}}{O^{l}} \frac{e^{h}}{e^{l}}$

The finding in (13) shows that the ratio of revenues of the two seasons is proportional to the occupancy ratio times the elasticity ratio. As illustrated in the introduction part, the demand tends to be less elastic in the high seasons (i.e., higher prices may not affect the demand) as compared to the low season, hence, the elasticity ratio is usually less than 1 , therefore, to maximize the profit, the revenue ratio must be

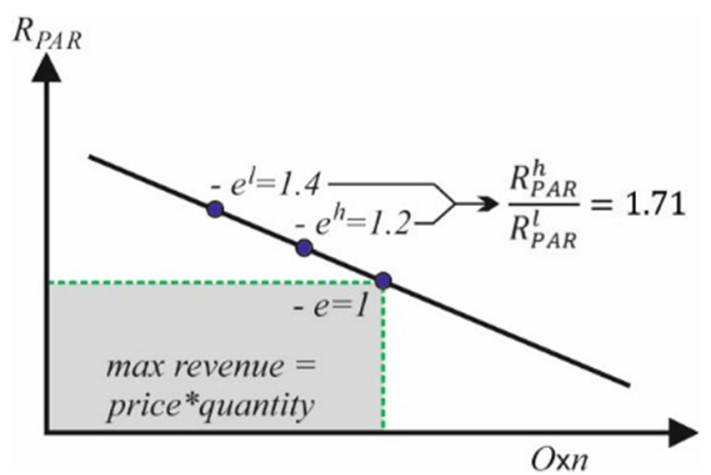

Fig. 5 The trend of elasticity lower than the occupancy ratio. Put differently, profit maximizing hotels should allow more seasonality in the occupancy rate than the revenue per available room, particularly in the low season where the demand is more likely to be elastic and sensitive to prices.

What we conclude from the above is that, to keep the marginal revenue equal across different seasons, the optimum approach requires setting the occupancy rates and revenue per available room according to Eq. (13). Clearly, for the same occupancy rate and RevPAR, the marginal revenue in high seasons is higher than the revenue of low seasons. To achieve profit maximization, the occupancy ratio and RevPAR ratios should be selected such that low season marginal revenue is increased and high season marginal revenue is decreased.

Lowering the marginal revenue in the high season entails relatively high occupancy rates since the marginal revenue is declining as a function of the occupancy rate. Similarly, to achieve an increase in the marginal revenue in low seasons, a reduction of occupancy rates is required. Forcing equal marginal revenue of the low and high seasons will result in a gap between the low and high season occupancy rates. As illustrated in Sect. 3, the occupancy rates are decreasing as a function of RevPAR, and the opposite is also correct for the ratio in the RevPAR that is needed to make the marginal revenue equal in both the low and high seasons.

\section{Behavior of profit maximization in local and international hotels}

In this study, data of 5-star local and international hotels in Dubai were collected to validate the presented model. The data were acquired from different paid and free sources to complete the given ratios in the subsequent bar charts below. These sources include: STR.com, www.thenational.ae/2019, http://www.arabianbusiness.com/, hospitalitynewsmag.com, www.statista.com, www.visitdubai.com/2019, Dubai Travel and Commerce Marketing (DTC) Annual Visitor Report 2019 and www.hotstat.com. The used classification scheme is shown in Fig. 6 for local and international 5-star hotels. Star ratings are employed according to UAE international tourism guidelines which can be found in (https://www. dubaitourism.gov.ae).

In Sect. 1, we have shown the occupancy rates for 2 years of both local and international hotels in Fig. 1. The low and high seasons in Dubai span the months of June-August and September-May, respectively. RevPAR has been averaged over each season, while the average occupancy has been collected/validated from/by the data sources given above.

Out of the 17 international hotels shown in Fig. 7, ten of them showed more seasonal variation in the RevPAR than the occupancy ratio. This can be easily identified by 
Fig. 6 Classification of the selected hotels

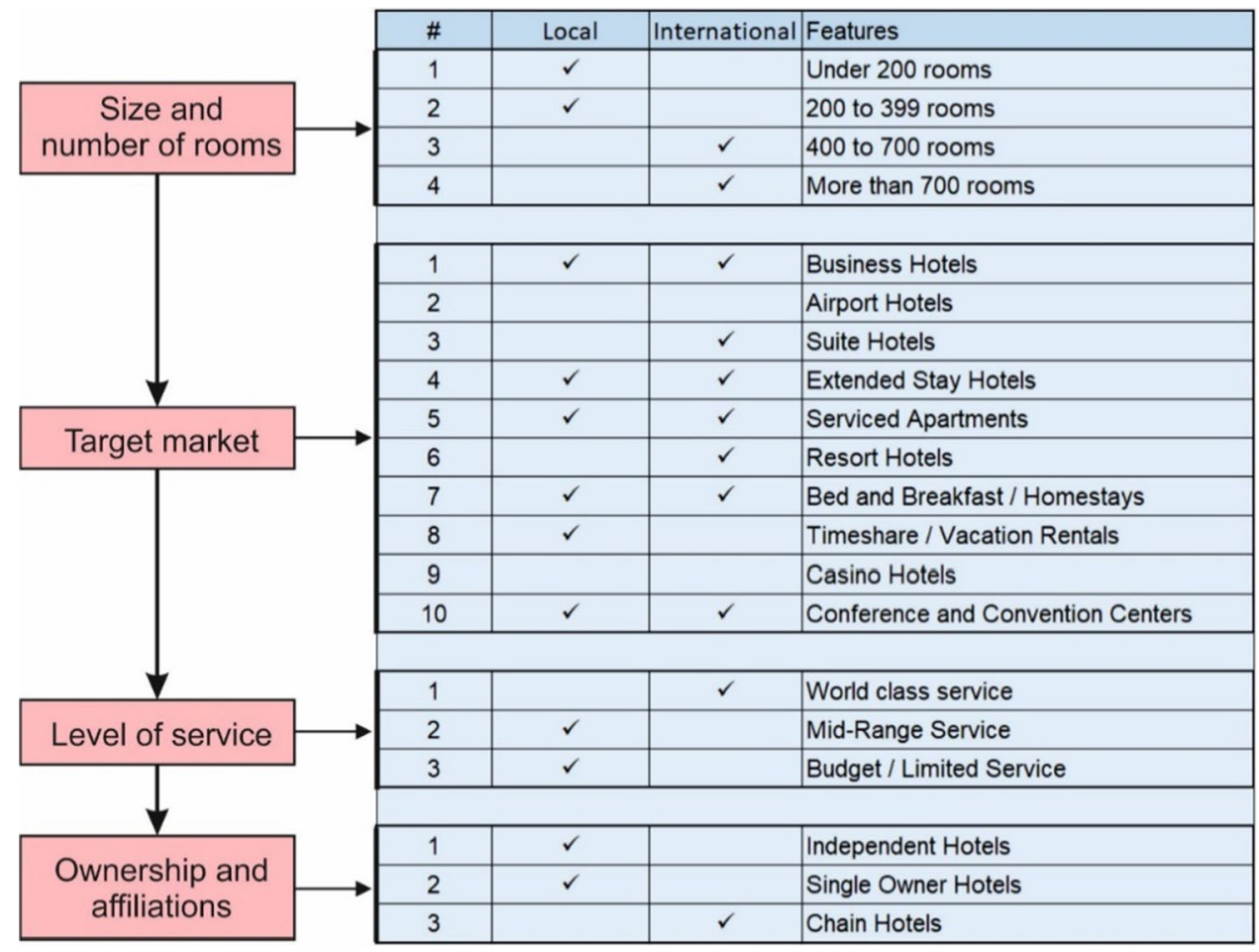

Fig. 7 Ratios of RevPAR and Occupancies of 17 international hotels in Dubai

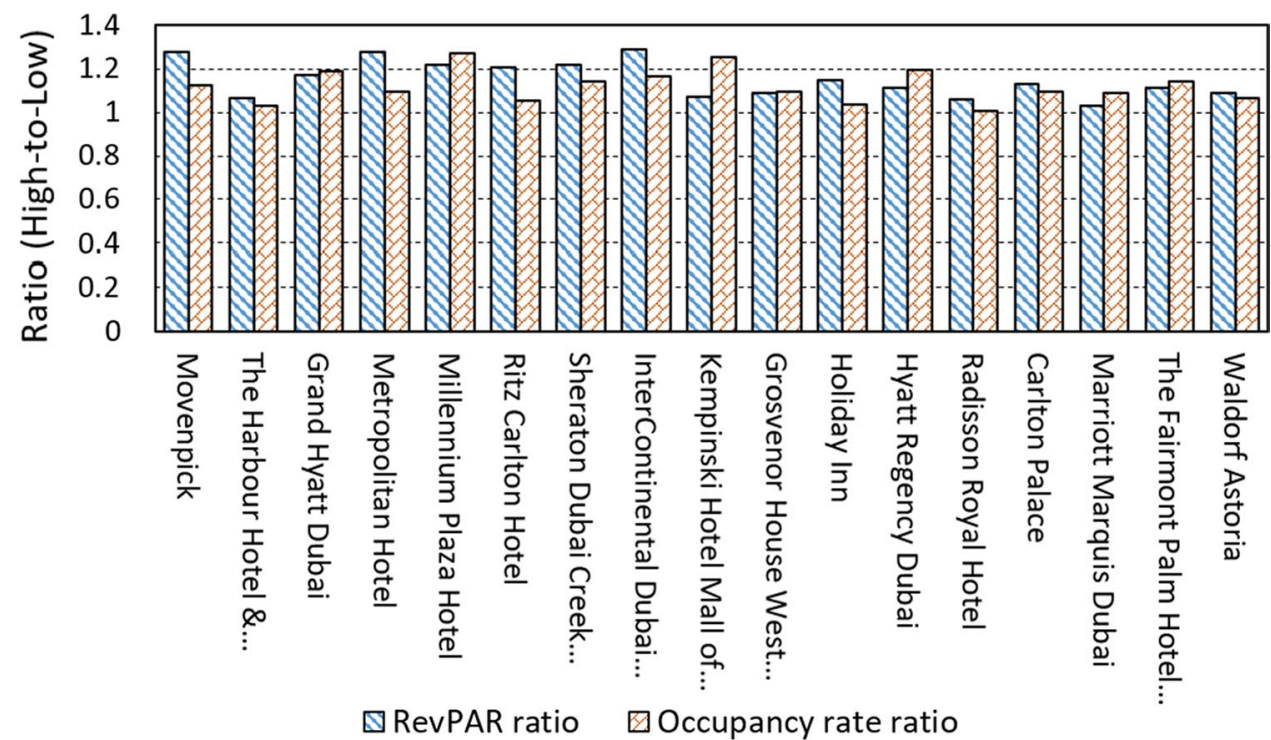

the higher blue-dashed bars than brown brick-filled bars of Fig. 7, which demonstrates inconsistency with our profit maximization model, that is, some hotels do not exhibit profit maximizing behavior. Metropolitan hotel seems to have the most incoherent seasonality balance between RevPAR and occupancy, where the RevPAR is $27.5 \%$ higher than the low season, while the occupancy is $10 \%$ higher than the low season.

In the remaining seven hotels, the seasonality in the occupancy rate appears to be stronger than the RevPAR which is an acceptable behavior that maximizes profits according to the proposed model here. Hotel Kempinski seems to be the most consistent in handling seasonality since the occupancy is as high as $25 \%$ while that of RevPAR is only $7 \%$.

One important finding of Fig. 7 is the ability to compute the elasticities of the demand for rooms that would be required to achieve profit maximization so as to stay in line with the results found in (13). To do so, let the occupancy ratio be denoted by $\alpha$ and the RevPAR ratio denoted by $\beta$, therefore. 
$=\left(\frac{1+e^{l}}{1+e^{h}}\right)$

and the RevPAR ratio is

$=\frac{e^{h}}{e^{l}}$

The following expression results from solving for the high and low elasticities:

$e^{l}=\frac{\alpha-1}{1-\beta}$

$e^{h}=\frac{\beta(\alpha-1)}{\alpha(1-\beta)}=e^{l} \frac{\beta}{\alpha}$

Note that the two parameters $\alpha$ and $\beta$ can be found easily from the data in Fig. 7 and hence the elasticities can be easily computed for every hotel. It is worth noting that those elasticities are only required to justify the occupancy rates and RevPAR ratios as profit maximizing values. In case real elasticities are different from those found here, the behavior of each hotel will not be a profit maximizing. The resulting elasticities are shown in Fig. 8.

To maximize profit, the demand of both high and low seasons should be elastic to RevPAR. This can be observed in hotels having an absolute value of elasticity that is higher than 1, here, those hotel are Grand Hyatt, Millennium, Kempinski, Grosvenor, Hyatt Regency, Marriott, and Fairmont, while the remaining tend to set their RevPAR or occupancy rates to other values that do not promise optimality.

Among the seven mentioned hotels, six hotels seem to require close elasticities of the two seasons, which is not possible under normal operation anyway. Only Kempinski shows a significant difference in the elasticities between the low and high seasons which indicates that out of the 17 hotels, only one could conceivably be balancing the occupancy rate with RevPAR so as to maximize profit in all seasons.

A similar analysis was conducted for 29 local hotels in Dubai which were selected according to the classification scheme in Fig. 6. In Fig. 9, it is apparent that local hotels do not face strong seasonality as much international hotels do.

While seasonality appears to be less noticeable in domestic hotels, Fig. 6 shows that 18 hotels exhibit seasonal variation in RevPAR more than the occupancy rate, a pattern that does not conform to profit maximization over the two seasons. Al-Khaleej grand hotel demonstrates the most seasonal variation between the two ratios. The remaining eleven hotels seem to be more consistent in their seasonal variation; with Al-Jawhara Metro Hotel being the most consistent by demonstrating a better balance between prices and room availability.

Most importantly, almost all domestic hotels assume inelastic demand in Dubai, which to a certain extent could be correct, where domestic hotels are less affected by seasonality and have higher chances to enjoy steady demand more than international hotels. This can be due to many reasons, among which could be the accessibility by locals for domestic hotels, while international hotels are more preferred to international tourists, which can be true since Dubai is one of the world's renowned international attraction visited by huge volume of international tourists. Moreover, domestic hotels do not have the solid ground and capacity to market their hospitality online as what international hotels can do, hence, they are accessible and trusted by the local community which have been hosted by such hotels. This justifies the elasticities being less than one in most of the hotels in
Fig. 8 The elasticities of 17 international hotels in Dubai

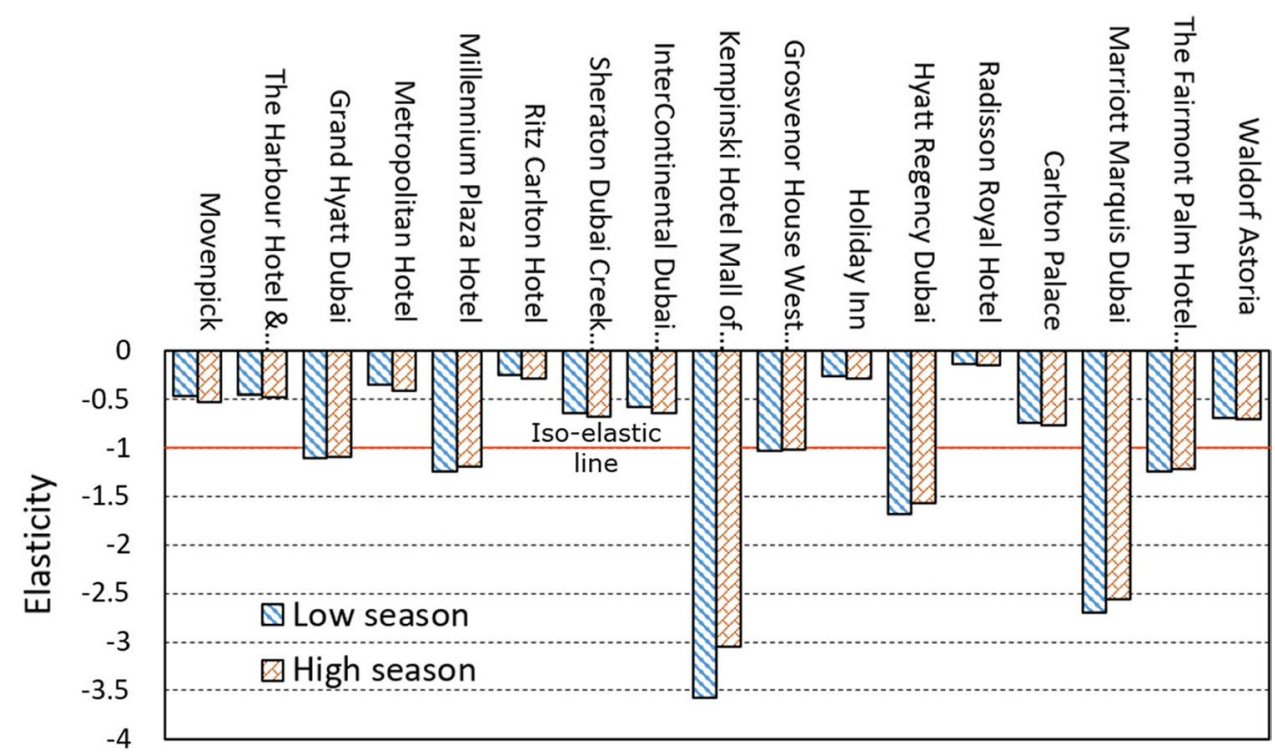


Fig. 9 The ratio of RevPAR and Occupancy rates for 29 local hotels in Dubai

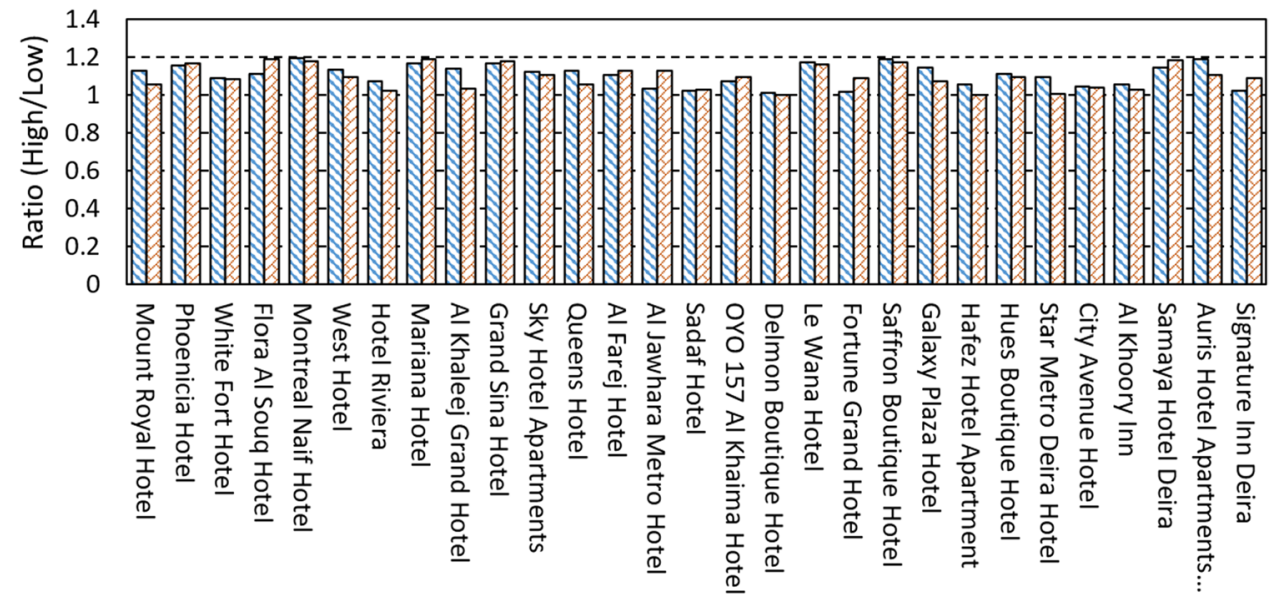

$\triangle$ RevPAR ratio $\square$ Occupancy rate ratio
Fig. 10 as compared to international hotels. Of those, only three assume high elasticity, namely, Al-Jawharah, Fortune and Signature hotels. However, none of the hotels demonstrates significant variation in the elasticities between the two seasons, which is justifiable by the fact that domestic hotels in Dubai are less prone to seasonality as compare to international hotels.

Bear in mind the above results, it can be noticed that only few hotels (Kempinski, and to some extent Signature, Furtuen and Al-Jawhara hotels) out of the 46 that are likely to be making profit maximization via manipulating room availability and revenue per available room. This dissatisfactory awareness of seasonality among most hotels is owed to the fact that hotel mangers push for higher revenue via changing the prices and do not work with costs and room availability, upgrading and upselling. Increasing the prices to push the revenue in the low seasons is not a profit maximizing behavior. Instead, lower prices stimulates higher demands in the low seasons.

\section{Discussion}

The results of "Behavior of profit maximization in local and international hotels" section show that international hotel chains in Dubai face more seasonal challenges as compared to domestic hotels. While this is not a reflection of the profit, however, with seasonality, hoteliers need to consider more attentive pricing that takes into consideration the elasticity, particularly in the low seasons. Out of the seventeen examined international hotels, while few assumed demand elasticity and agree that prices may affect the demand, only

Fig. 10 The elasticities of 29 local hotels in Dubai

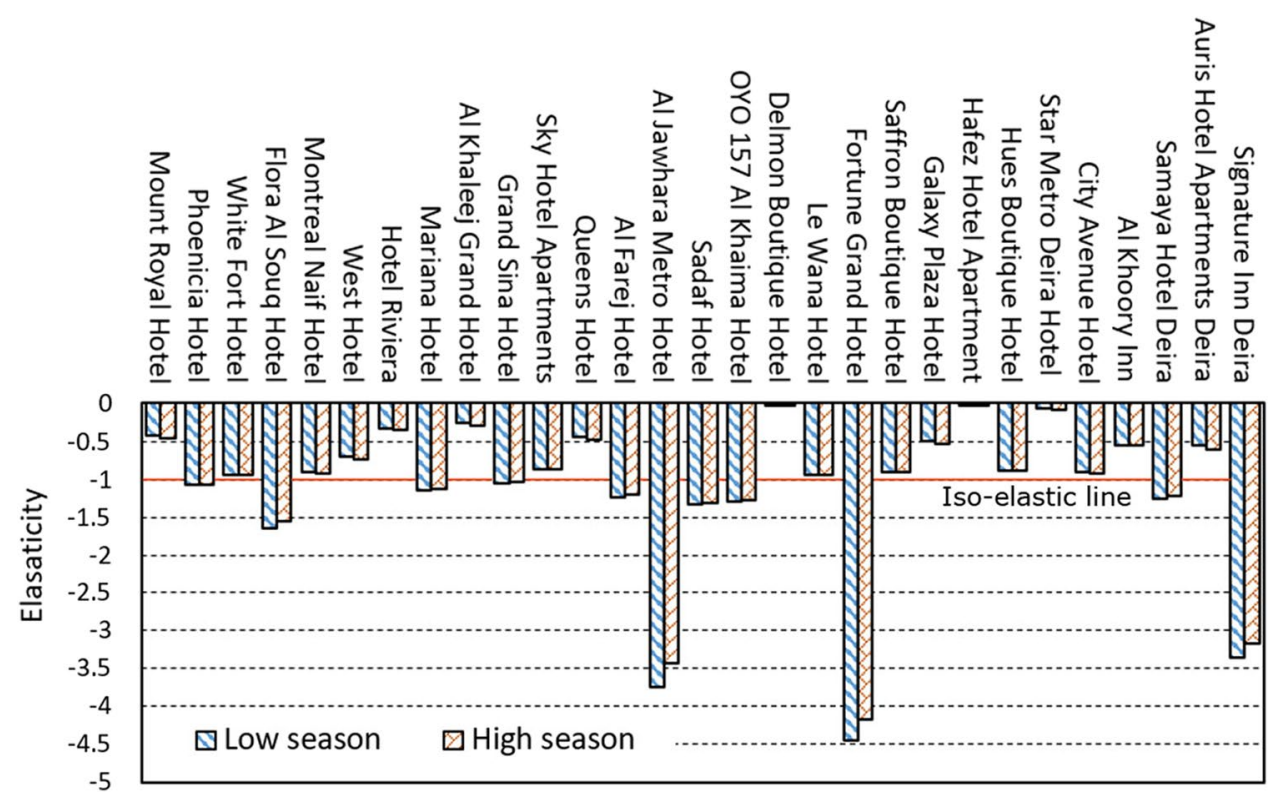


one hotel was found to carefully set pricing that may maximize the profit under seasonality. In contrast, the demand in domestic hotels seems to be less responsive to prices as most of the hotels exhibit low elasticity. Moreover, the seasonal adjustment in prices vs. room offerings was not significant in this category as the elasticities between the low and high seasons seem to be steady with low variations.

Furthermore, low seasons exert more pressure on hotels as hoteliers need to decide on the best prices and room offerings to maintain a good balance for profit maximization. High offerings in the low season will worsen the profit margin, while low prices may boom the demand particularly in the low seasons.

Although the proposed approach in this study does not suggest explicit prices or suitable occupancy rates, it benchmarks the performance of a hotel relative to profit maximization under seasonal variations. As for the city of Dubai, the governor Shk Mhd Bin Rashid is encouraging business travel growth prospects by facilitating entries and leading creativity in the sector of meetings, incentives, conferences and exhibits (MICE) by literally providing corporate travelers a cache of value adds. These initiatives not only have enhanced the city with a well-rounded visit experience, but also allowed the MICE sector of the UAE to build this synergy with indirectly linked sectors such as leisure, shopping and cultural attractions. The outcome of these efforts can be noticed by the intentional recognition of the achievements of the city. Among many recognitions that can be listed, in 2019, UAE was given the award 'World's Leading MICE Destination 2019'. The latest achievements of the city at the World Travel Awards 2019 are testaments to the ongoing efforts to demonstrate the capabilities of Dubai on the global stage. This accomplishment takes the city's emphasis on creativity, entrepreneurship, and economic development to the forefront while leveraging its potential through a continually changing business-enabling environment.

\section{Conclusion}

Using different business models in this work, we established a model to examine whether hotels behave differently in response to the typical price-demand patterns. The main goal of this article was to demonstrate an empirical evidence of profit maximization in hotel industry via the existing ratios of prices and room occupancy rates for better revenue management. The proposed profit maximization model of this work suggests that hoteliers' behavior should consider seasonality, particularly, in low season when the demand is more responsive to prices. Under this model, room upgradability and availability are found to be more important to profit maximization than increasing the revenue per available room.
The main findings of this article falls in twofold: first, the hoteliers should balance the revenues via both prices and room availability; second, the demand elasticity is much higher in the low seasons, which requires understanding of the price and demand function to better maximize the profit. This would help hotel professionals who can rely on conventional methods of pricing to have better insights to the implications of pricing and demand. It was also shown that domestic hotels exhibit less seasonality owing to ties with surrounding community. In such class of hotels, lower profit margins may be achieved. Yet the profit appears to be notably steady with less risks resulting from seasonality.

Our profit maximization model shows, via seasonality in occupancy rates and average RevPAR, that only one from the international hotels and almost none of the domestic hotels adhere to rational seasonal adjustments. It was observed that stronger seasonality in prices is observed as compared to occupancy factor, which is inconsistent with the profit maximization model.

Lastly, successful managers should recognize the market variability in their services to better place their hotels on the performance map. Through promoting channels of direct bookings, hotels can catch some of the offered rates while avoiding commission fees charged to OTAs. Tourists should also recognize that while networked web applications, social media, and cloud computing have helped make hotel data freely accessible, there are often price disparities between platforms and service providers. A limitation of this study that may be considered in future work is the use of RevPAR and occupancy rates across all different hotel rooms. One also could separate the classes according to the types of rooms or suites which may face different demand patterns. However, this requires more detailed data collection that may not be generously available. Other venues for future extensions may consider this model along with different types of pricing policies such as offers for group or corporate deals.

\section{References}

Abrate, G., and G. Viglia. 2016. Strategic and tactical price decisions in hotel revenue management. Tourism Management 55: 123-132. https://doi.org/10.1016/j.tourman.2016.02.006.

Arora, S.D., and S. Mathur. 2020. Hotel pricing at tourist destinations-A comparison across emerging and developed markets. Tourism Management Perspectives 35: 100724. https://doi. org/10.1016/j.tmp.2020.100724.

Assaf, A.G., and L.K. Cvelbar. 2015. Why Negative Outputs are Often Ignored: A Comprehensive Measure of Hotel Performance. Tourism Economics 21 (4): 761-773. https://doi.org/10.5367/ te.2014.0386.

Assaf, A.G., A. Josiassen, L.K. Cvelbar, and L. Woo. 2015. The effects of customer voice on hotel performance. International Journal of Hospitality Management 44: 77-83. https://doi.org/10.1016/j. ijhm.2014.09.009. 
Baud-Bovy, M. 1982. New concepts in planning for tourism and recreation. Tourism Management 3 (4): 308-313. https://doi. org/10.1016/0261-5177(82)90056-5.

Becerra, M., J. Santaló, and R. Silva. 2013. Being better vs. being different: Differentiation, competition, and pricing strategies in the Spanish hotel industry. Tourism Management 34: 71-79. https:// doi.org/10.1016/j.tourman.2012.03.014.

Beerli-Palacio, A., J.D. Martín-Santana, and C. Román-Montoya. 2020. Complementary services at hotels in accordance with their pricing strategy and the price sensitivity of tourists. International Journal of Hospitality Management 87: 102458. https://doi.org/10.1016/j. ijhm.2020.102458.

Botts, R., N. Graham, R. McDowell, and D. Sjolander. 2012. Finding the right mix: Exploring effective distribution channel management. 2012 Hotel Data Conference.

Cantallops, A.S., and F. Salvi. 2014. International Journal of Hospitality Management New consumer behavior: A review of research on eWOM and hotels. International Journal of Hospitality Management. https://doi.org/10.1016/j.ijhm.2013.08.007.

Chang, Y.-W., P.-Y. Hsu, and Y.-C. Lan. 2019. Cooperation and competition between online travel agencies and hotels. Tourism Management 71: 187-196. https://doi.org/10.1016/j.tourman.2018.08.026.

Chen, C.F., and R. Rothschild. 2010. An application of hedonic pricing analysis to the case of hotel rooms in Taipei. Tourism Economics. https://doi.org/10.5367/000000010792278310.

Chen, W., H. Liu, and D. Xu. 2018. Dynamic pricing strategies for perishable product in a competitive multi-agent retailers market. Journal of Artificial Societies and Social Simulation 21 (2): 12. https://doi.org/10.18564/jasss.3710.

de la Peña, M.R., J.A. Núñez-Serrano, J. Turrión, and F.J. Velázquez. 2016. Are innovations relevant for consumers in the hospitality industry? A hedonic approach for Cuban hotels. Tourism Management. https://doi.org/10.1016/j.tourman.2016.02.009.

Dogru, T., M. Mody, N. Line, C. Suess, L. Hanks, and M. Bonn. 2020. Investigating the whole picture: Comparing the effects of Airbnb supply and hotel supply on hotel performance across the United States. Tourism Management 79: 104094. https://doi. org/10.1016/j.tourman.2020.104094.

Esteves, R.-B., and C. Reggiani. 2014. Elasticity of demand and behaviour-based price discrimination. International Journal of Industrial Organization 32: 46-56. https://doi.org/10.1016/j.ijind org.2013.10.010.

Hanna, R.C., K.N. Lemon, and G.E. Smith. 2019. Is transparency a good thing? How online price transparency and variability can benefit firms and influence consumer decision making. Business Horizons 62 (2): 227-236. https://doi.org/10.1016/j.busho r.2018.11.006.

Haynes, N., and D. Egan. 2015. The Future Impact of Changes in Rate Parity Agreements on Hotel Chains: The long-term implications of the removal of rate parity agreements between hotels and online travel agents using closed consumer group booking models. Journal of Travel \& Tourism Marketing 32 (7): 923-933. https://doi. org/10.1080/10548408.2015.1063897.

Israeli, A.A. 2002. Star rating and corporate affiliation: Their influence on room price and performance of hotels in Israel. International Journal of Hospitality Management. https://doi.org/10.1016/ S0278-4319(02)00037-3.

Ivanov, S., and K. Piddubna. 2016. Analysis of prices of accommodation establishments in kiev: \{Determinants\}, dynamics and parity. International Journal of Revenue Management 9 (4): 1-9.

Kim, J., S. Jang, S. Kang, and S.H. Kim. 2020a. Why are hotel room prices different? Exploring spatially varying relationships between room price and hotel attributes. Journal of Business Research 107: 118-129. https://doi.org/10.1016/j.jbusres.2018.09.006.

Kim, J., S. Jang, S. Kang, S.H. Kim, and (James). . 2020b. Why are hotel room prices different? Exploring spatially varying relationships between room price and hotel attributes. Journal of Business Research. https://doi.org/10.1016/j.jbusr es.2018.09.006

Kim, W.G., S. McGinley, H.-M. Choi, E. Luberto, and J. Li. 2020c. How does room rate and rate dispersion in U.S. hotels fluctuate? Journal of Hospitality and Tourism Management 44: 227-237. https://doi.org/10.1016/j.jhtm.2020.06.014.

Latinopoulos, D. 2018. Using a spatial hedonic analysis to evaluate the effect of sea view on hotel prices. Tourism Management. https:// doi.org/10.1016/j.tourman.2017.09.019.

Lee, S.K., and S. Jang. 2012. Premium or discount in hotel room rates? The dual effects of a central downtown location. Cornell Hospitality Quarterly 53 (2): 165-173. https://doi.org/10.1177/19389 65512441056.

Leong, C.C., and T.-K. Hui. 2014. Macroeconomic and non-macroeconomic variables linking to singapore hotel stock returns. In Advances in hospitality and leisure, ed. C.C. Leong and T.-K. Hui, 21-36. Bingley: Emerald Group Publishing Limited.

Nakamura, E., J. Steinsson, P. Sun, and D. Villar. 2018. The elusive costs of inflation: Price dispersion during the U.S. great inflation*. Quarterly Journal of Economics 133: 1933-1980. https:// doi.org/10.1093/qje/qjy017.

Nalley, M.E., J.-Y. Park, and D. Bufquin. 2019. An investigation of AAA diamond rating changes on hotel performance. International Journal of Hospitality Management 77: 365-374. https:// doi.org/10.1016/j.ijhm.2018.07.016.

Nicolau, J.L., and A. Sharma. 2019. To ban or not to ban rate parity, that is the question... or not? International Journal of Hospitality Management 77: 523-527.

Pawlicz, A., and T. Napierala. 2017. The determinants of hotel room rates: An analysis of the hotel industry in Warsaw, Poland. International Journal of Contemporary Hospitality Management. https ://doi.org/10.1108/IJCHM-12-2015-0694.

PhoCusWright. 2018. PhoCusWright's U.S. online travel overview (17th ed.). http://www.phocuswright.com, Accessed 9 January .

Pimentel, V., A. Aizezikali, and T. Baker. 2019. Hotel revenue management: Benefits of simultaneous overbooking and allocation problem formulation in price optimization. Computers and Industrial Engineering 137 (September): 106073. https://doi.org/10.1016/j. cie.2019.106073.

Saed, R.. Al., A. Upadhya, and M.A. Saleh. 2020. Role of airline promotion activities in destination branding: Case of Dubai vis-à-vis Emirates Airline. European Research on Management and Business Economics 26 (3): 121-126.

Santana-Jiménez, Y., Y.Y. Sun, J.M. Hernández, and R. Suárez-Vega. 2015. The influence of remoteness and isolation in the rural accommodation rental price among Eastern and Western destinations. Journal of Travel Research. https://doi.org/10.1177/00472 87513517423.

Schamel, G. 2012. Weekend vs. midweek stays: Modelling hotel room rates in a small market. International Journal of Hospitality Management. https://doi.org/10.1016/j.ijhm.2012.01.008.

Sharma, A., and J.L. Nicolau. 2019. Hotels to OTAs: Hands off my rates!? the economic consequences of the rate parity legislative actions in europe and the US. Tourism Management 75: 1-8.

Sheremirov, V. 2020. Price dispersion and inflation: New facts and theoretical implications. Journal of Monetary Economics 114: 59-70. https://doi.org/10.1016/j.jmoneco.2019.03.007.

Soler, I.P., and G. Gemar. 2018. Hedonic price models with geographically weighted regression: An application to hospitality. Journal of Destination Marketing and Management. https://doi. org/10.1016/j.jdmm.2017.12.001.

Stangl, B., A. Inversini, and R. Schegg. 2016. Hotels' dependency on online intermediaries and their chosen distribution channel portfolios: Three country insights. International Journal of Hospitality Management. https://doi.org/10.1016/j.ijhm.2015.09.015. 
Thrane, C. 2007. Examining the determinants of room rates for hotels in capital cities: The Oslo experience. Journal of Revenue and Pricing Management. https://doi.org/10.1057/palgrave.rpm.51600 55.

WTO. 2018. World Tourism Organization, ed. 2018. United Nations, https://www.e-unwto.org/. https://www.e-unwto.org/

Wu, B., and W. Yang. 2018. What do Chinese consumers want? A value framework for luxury hotels in China. International Journal of Contemporary Hospitality Management 30 (4): 2037-2055. https://doi.org/10.1108/ijchm-08-2016-0466.

Yang, Z., and J. Cai. 2016. Do regional factors matter? Determinants of hotel industry performance in China. Tourism Management 52: 242-253. https://doi.org/10.1016/j.tourman.2015.06.024.

Ye, Q., R. Law, B. Gu, and W. Chen. 2011. The influence of user-generated content on traveler behavior: An empirical investigation on the effects of e-word-of-mouth to hotel online bookings. Computers in Human Behavior 27 (2): 634-639. https://doi.org/10.1016/j. chb.2010.04.014.

Zervas, G., D. Proserpio, and J. Byers. 2015. A first look at online reputation on airbnb, where every stay is above average. SSRN Electronic Journal. https://doi.org/10.2139/ssrn.2554500.

Zhang, D., J. Tu, L. Zhou, and Z. Yu. 2020. Higher tourism specialization, better hotel industry efficiency? International Journal of Hospitality Management 87: 102509. https://doi.org/10.1016/j. ijhm.2020.102509.
Zhang, H., J. Zhang, S. Lu, S. Cheng, and J. Zhang. 2011. Modeling hotel room price with geographically weighted regression. International Journal of Hospitality Management. https://doi. org/10.1016/j.ijhm.2011.03.010.

Ziqiong, Z., Y. Qiang, and L. Rob. 2011. Determinants of hotel room price: An exploration of travelers' hierarchy of accommodation needs. International Journal of Contemporary Hospitality Management 23: 972 .

Publisher's Note Springer Nature remains neutral with regard to jurisdictional claims in published maps and institutional affiliations.

Wasfi Alrawabdeh holds a $\mathrm{PhD}$ in Marketing from the University of Kent, UK and an MBA from University of Bridgeport, Connecticut, USA. Currently, he is the dean of the faculty of business and administration science at the Hashemite University in Jordan. His current research interests include global e-commerce, commerce technology, e-business, adoption, and use of IT. He has ten years of experience managing different department stores in the State of Connecticut, USA. Alrawabdeh has published more than 20 scientific articles in well-known journals and a Book entitled "Advanced Communication Skills" which was published in 2019. 